\title{
Microbiological assay of protein quality with Tetrahymena pyriformis $\mathrm{W}$
}

\section{4.* Measurement of available lysine, methionine, arginine and histidine}

\author{
By J. A. STOTT AND H. SMITH \\ Research Department, $\mathcal{F}$. Bibby and Sons Ltd, \\ King Edward Street, Liverpool 3

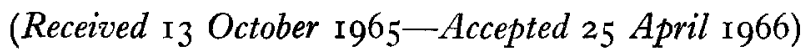

\begin{abstract}
I. A microbiological assay using the protozoan Tetrahymena pyriformis $\mathrm{W}$ for measurement of available lysine, methionine, arginine and histidine is described and the application of the assay is illustrated by values for available amino acid content of a wide range of animal and vegetable protein sources. 2. Comparison with values reported by Boyne, Carpenter \& Woodham (1961) and Miller, Carpenter \& Milner (1965) for animal protein sources showed Tetrahymena estimates of available lysine to be similar to those obtained by the fluorodinitrobenzene (FDNB) method of Carpenter $(1960)$ for samples with higher available lysine content (c. $8 \mathrm{~g} / 16 \mathrm{~g} \mathrm{~N}$ ) but lower than FDNB values for samples with lower available lysine content. 3. Tetrahymena assays of available lysine in groundnut meals and soya-bean meals showed little variation between samples of one type of oilseed meal. The values obtained also suggest that modern commercial processing has little or no effect on lysine availability in groundnut and soya-bean meals. There was considerable variation between samples in the available lysine content of cottonseed meals, possibly due to binding of lysine by the gossypol present in these meals. 4 . There also appeared to be considerable variation in the available lysine and methionine content of different samples of the same type of cereal.
\end{abstract}

Measurement of the quantity of an essential amino acid which is available for use by an animal, as opposed to the total present in a feeding-stuff, is rapidly becoming accepted as a necessity in evaluation of protein sources. Such information is of wider application than the overall nutritive value under particular dietary conditions, since supplementary effects of two or more protein sources in combination may be foreseen better through a prior knowledge of available amino acid content.

Biological tests designed to measure available amino acid content require a basal diet free from, or low in, the amino acid to be measured. This requirement places certain practical difficulties of diet preparation in the way of the research worker who wishes to use higher animals, although sesame meal, low in lysine content, and groundnut meal, low in methionine content, go some way towards solving the problem. Against this background, microbiological assays offer the prospect of a test organism readily grown on free amino acids and for which a variety of basal media, each free of one essential amino acid, may be easily prepared.

The requirement of Tetrahymena pyriformis $\mathrm{W}$ for the same ten essential amino acids as the growing rat (Kidder \& Dewey, 195I), together with the ability to utilize intact protein, makes this organism of particular value for measurement of the biological availability of amino acids. Culture techniques for assays of the nutritive value of proteins with Tetrahymena have been reported (Rosen \& Fernell, 1956; Teunisson,

* Paper no. 3: Br. F. Nutr. (1963), r7, 227. 
196I; Stott, Smith \& Rosen, 1963). The present paper describes the application of Tetrahymena assays to the measurement of available lysine, methionine, arginine and histidine.

\section{EXPER I MEN TAL}

The general assay technique was that of Stott $e t a l .(1963)$; the procedure for assay of available amino acids is outlined below.

Amino acid solution $F$. The composition of the amino acid solution, based on the $2 \mathrm{C}$ medium of Kidder \& Dewey (195I), is given in Table I. The amino acid to be measured was omitted from this solution.

Amino acid response curves. The levels per $10 \mathrm{ml}$ of assay medium (i.e. per assay bottle) for the various essential amino acids were: $(a)$ L-lysine hydrochloride, $0-3 \cdot 5 \mathrm{mg}$ in $0.25 \mathrm{mg}$ increments; $(b)$ L-methionine, $0-0.8 \mathrm{mg}$ in $0.1 \mathrm{mg}$ increments; $(c)$ L-arginine hydrochloride, $0-3.0 \mathrm{mg}$ in $0.25 \mathrm{mg}$ increments; $(d)$ L-histidine hydrochloride, $0-0.7 \mathrm{mg}$ in $0.05 \mathrm{mg}$ increments. Solutions containing the highest amino acid level in $\mathrm{I} \mathrm{ml}$ were prepared, and solutions containing the appropriate lower levels were obtained by dilution. Fig. I illustrates response curves obtained for the above amino acids.

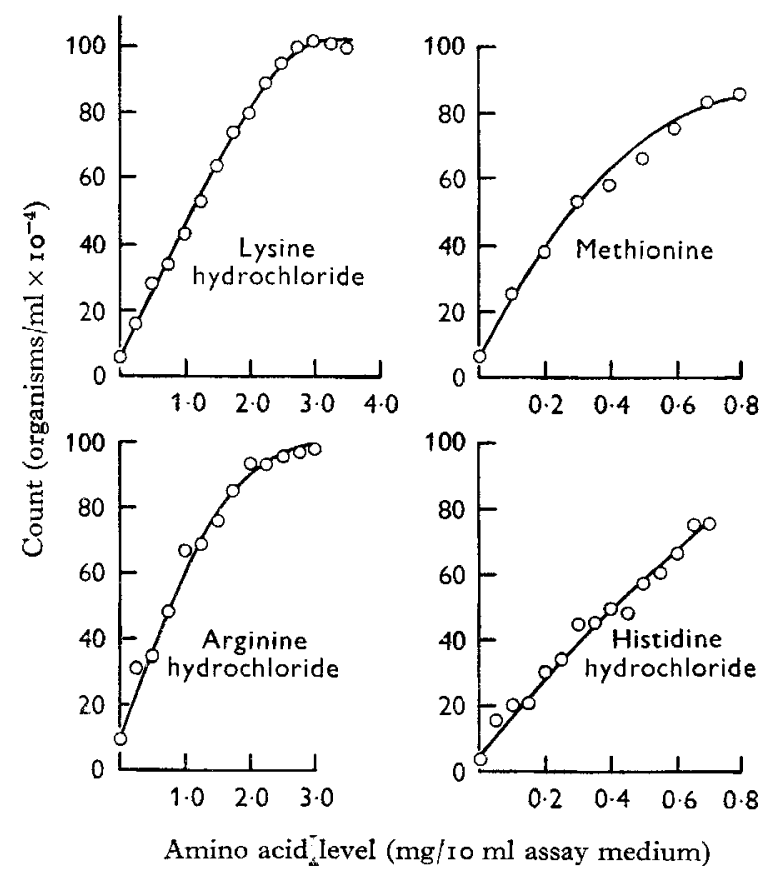

Fig. I. Growth response of Tetrahymena pyriformis $\mathrm{W}$ to lysine hydrochloride, methionine, arginine hydrochloride and histidine hydrochloride at various levels in the assay medium.

Solution G. Io $\mathrm{ml} \mathrm{of} 30 \%$ glucose, $2 \mathrm{ml}$ solution A (Table $\mathrm{I}$ ) and $80 \mathrm{ml}$ solution $\mathrm{F}$ were made up to $100 \mathrm{ml}$ with distilled water to give solution $\mathrm{G}$, which was twice as strong as in the final medium.

Test material suspensions. These were usually prepared to contain $5 \mathrm{mg}$ nitrogen $/ 3 \mathrm{ml}$ and dilutions made from this suspension to give a range of $2-5 \mathrm{mg} \mathrm{N} / 3 \mathrm{ml}$ in I $\mathrm{mg}$ 


\section{Table I. Composition of stock solutions, and solutions $E, F$ and $G$}

Stock solution A ( 100 times final strength)

Calcium pantothenate

$\mathrm{mg} / 200 \mathrm{ml}$

Nicotinamide

I2. 5

Pyridoxine hydrochloride

I $2 \cdot 5$

Pyridoxal hydrochloride

$125^{\circ} \mathrm{O}$

Pyridoxamine hydrochloride

$12 \cdot 5$

Riboflavine

$12 \cdot 5$

Folic acid

$12 \cdot 5$

Thiamine hydrochloride

Inositol

$125 \cdot 0$

Choline chloride

$12 \cdot 5$

125.0

p-Aminobenzoic acid

I $2 \cdot 5$

Biotin

I. 25

DL- $\alpha$-Lipoic acid

Stock solution $\mathrm{B}$ ( I 00 times final strength)

$\mathrm{MgSO}_{4} \cdot 7 \mathrm{H}_{2} \mathrm{O}$

$\mathrm{g} / 200 \mathrm{ml}$

2.8

$\mathrm{I} \cdot 25$

$\mathrm{Fe}\left(\mathrm{NH}_{4}\right)_{2}\left(\mathrm{SO}_{4}\right)_{2} \cdot 6 \mathrm{H}_{2} \mathrm{O}$

0.025

$\mathrm{ZnCl}_{2}$

0.0025

Stock solution $\mathrm{C}$ ( Ioo times final strength)

$\mathrm{mg} / 200 \mathrm{ml}$

600

$\mathrm{CaCl}_{2} \cdot 2 \mathrm{H}_{2} \mathrm{O}$

$\mathrm{CuCl}_{2}, 2 \mathrm{H}_{2} \mathrm{O}$

$\mathrm{FeCl}_{3} \cdot 6 \mathrm{H}_{2} \mathrm{O}$

60

I 5

$\mathrm{g} / 200 \mathrm{ml}$

$3 \cdot 5$

$\mathrm{KH}_{2} \mathrm{PO}_{4}$

3.5

Solution $\mathrm{E}$ ( 5 times final strength)

The appropriate weights of the components listed below were dissolved in approximately ro $\mathrm{ml}$ distilled water, $\mathrm{I} \mathrm{ml}$ stock solutions $\mathrm{B}, \mathrm{C}, \mathrm{D}$ were added and the whole was made up to $20 \mathrm{ml}$, the $\mathrm{pH}$ being adjusted to $7 \cdot \mathrm{I}$ with $\mathrm{NaOH}$

Guanylic acid (sodium salt) solution $\mathrm{E}$

Adenosine-2' $\left(3^{\prime}\right)$-phosphoric acid monohydrate

I5

Cytidylic acid

Uracil

$12 \cdot 5$

Solution F (2 $\frac{1}{2}$ times final strength)

$$
5
$$

DL-Alanine

$\mathrm{mg} / \mathrm{I} 00 \mathrm{ml}$

L-Arginine hydrochloride

$97 \cdot 8$

L-Aspartic acid

$93 \cdot 0$

$108 \cdot 7$

Glycine

L-Glutamic acid

$207 \cdot 2$

L-Histidine hydrochloride

$46 \cdot 2$

L-Isoleucine

$56 \cdot 0$

L-Phenylalanine

L-Methionine

L-Proline

I $56 \cdot 4$

L-Leucine

173.0

L-Cystine*

20.0

DL-Serine

I 37.4

L-Threonine

$78 \cdot 4$

L-Tryptophan

$2 \mathrm{I} \cdot 3$

Dt-Valine

I $17 \cdot 6$

Solution $\mathbf{G}$ :

L-I ysine hydrochloridc

I $67 \cdot 2$

ro $\mathrm{ml} 30 \%$ glucose solution $+2 \mathrm{ml}$ solution $\mathrm{A}+80 \mathrm{ml}$ solution $\mathbf{F}$ made up to roo $\mathrm{ml}$ at $\mathrm{pH} 7 \cdot \mathrm{I}$, the $\mathrm{pH}$ being adjusted with $\mathrm{NaOH}$

* Dissolved separately with $\mathrm{NaOH}$. 
steps. Higher $\mathrm{N}$ levels were used for materials of low available amino acid content. Thus, whereas $2-5 \mathrm{mg} \mathrm{N} / 3 \mathrm{ml}$ were sufficient to give a suitable growth response on a commercial soya-bean meal, 9-12 $\mathrm{mg} \mathrm{N} / 3 \mathrm{ml}$ were required in assays of a heatdamaged soya-bean meal. Samples were assayed in duplicate at each $\mathrm{N}$ level. All suspensions of test materials were adjusted to $\mathrm{pH} 8 \cdot 2$ to ensure that the $\mathrm{pH}$ did not fall below $7 \cdot \mathrm{I}$ when the test material plus solution $\mathrm{E}$ was autoclaved.

Assay medium. This consisted of: (a) $2 \mathrm{ml}$ of solution E (Table $\mathrm{r}$ ), (b) $3 \mathrm{ml}$ of $3 \frac{1}{3}$ times strength test material suspension or $\mathrm{r} \mathrm{ml}$ of ro times strength solution of the amino acid to be estimated plus $2 \mathrm{ml}$ distilled water. After sterilizing the above solutions in $2 \mathrm{oz}$ screw-capped 'medical flat' assay bottles at $12 \mathrm{r}^{\circ}$ for $10 \mathrm{~min}, 5 \mathrm{ml}$ of sterile solution $G$ were added aseptically to each bottle.

Incubation. Each bottle was inoculated with three drops of a 3-day broth culture of T. pyriformis $\mathrm{W}$, and inoculated at $25^{\circ}$ for 4 days. The screw caps were left loose during this period and the bottles were inclined at $15^{\circ}$ to the horizontal to provide sufficient aeration for rapid growth.

Measurement of growth response. After 4 days' incubation, I $\mathrm{ml}$ of the culture medium was transferred to a $\frac{1}{4} \mathrm{oz}$ screw-capped bottle containing $\mathrm{I} \mathrm{ml}$ preserving fluid (consisting of $90 \mathrm{ml}$ water, $20 \mathrm{ml} 36 \%$ (w/v) formaldehyde and $10 \mathrm{ml}$ of stock solution D ('Table 1 ). Organisms were counted in a haemocytometer, depth $0.2 \mathrm{~mm}$, FuchsRosenthal rulings to $\mathrm{BS} 748$. The organisms in eight I mm squares were counted and the mean number per I $\mathrm{mm}$ square gave the final population of the test culture in units of $10^{4}$ organisms $/ \mathrm{ml}$.

Calculation of available amino acid content. Values for the test materials were read off from the response curve for the pure amino acid. The values reported are the mean for the four $\mathrm{N}$ levels used, except that values differing by more than $20 \%$ from the mean were rejected. The latter course was seldom necessary.

Error of estimates. Statistical analysis of four individual experiments for measurement of available lysine gave coefficients of variation ranging from 7.6 to $13.0 \%$. Similar analyses of four available methionine assays gave coefficients of variation ranging from $9.7 \%$ to $14.4 \%$. Fewer values were available for arginine and histidine assays, but coefficients of variation in one assay for each amino acid were $14.2 \%$ for histidine and $8.3 \%$ for arginine.

Origin of samples. Many of the protein concentrates were distributed as part of a collaborative study arranged by the Agricultural Research Council (Boyne et al. r96r) and the code numbers are those used by all collaborating laboratories. The additional soya-bean meals were obtained before and after solvent extraction in a large-scale plant. The cod fillet and anchovy meal samples were kindly supplied by Dr K. J. Carpenter, University of Cambridge. The results of other investigations on these samples have been published by Carpenter, March, Milner \& Campbell (1963) and by Miller et al. (1965).

Treatment of soya meals. Samples of the untoasted, air-dried, solvent-extracted material were heated in the laboratory autoclave for $1 \frac{1}{2} h$ or $2 \frac{1}{2} h$ at $12 I^{\circ}$. 


\section{RESULTS}

Results for $T$. pyriformis assays of available lysine in a wide range of meat meals, whale meat meals and fish meals are given in Table 2. Also tabulated are 'available lysine values' obtained by the fluorodinitrobenzene (FDNB) method of Carpenter, Ellinger, Munro \& Rolfe (1957) and gross protein values (GPV) (Heiman, Carver \& Cook, 1939), both sets of values being those reported by Boyne et al. (I96r).

Table 2. Available lysine $(\mathrm{g} / \mathrm{1} 6 \mathrm{~g} N)$ in meat meals, meat-and-bone meals, whale meat meals and fish meals

Sample $\quad \overbrace{\text { Tetrahymena }}^{\text {Available lysine value }} \overbrace{\text { FDNB }}^{*} \quad \begin{gathered}\text { Gross protein } \\ \text { value* }\end{gathered}$

Meat meals and meat-and-bone meals:

$\begin{array}{rlll}\text { MMI I } & 2 \cdot 6 & 3 \cdot 9 & 7 I \\ 2 & 3 \cdot 1 & 4 \cdot 0 & 70 \\ 3 & 1 \cdot 9 & 3 \cdot 9 & 64 \\ 5 & 1 \cdot 3 & 3 \cdot 9 & 68 \\ 6 & 4 \cdot 0 & 4 \cdot 1 & 73 \\ \text { I0 } & 2 \cdot 5 & 3 \cdot 6 & 64 \\ \text { I2 } & 2 \cdot 3 & 2 \cdot 9 & 6 I \\ \text { I6 } & 1 \cdot 6 & 2 \cdot 7 & 39 \\ \text { I8 } & 4 \cdot 0 & 4 \cdot 7 & 87 \\ 22 & 3 \cdot 3 & 3 \cdot 3 & 57 \\ 23 & 3 \cdot 2 & 4 \cdot 4 & 91 \\ 25 & 2 \cdot 9 & 4 \cdot 0 & 80\end{array}$

Whale meat meals:

\begin{tabular}{|c|c|c|c|c|}
\hline \\
\hline & WM I & $4 \cdot 4$ & 4.9 & 77 \\
\hline & 2 & $3 \cdot 5$ & 5.8 & 86 \\
\hline & 3 & $3 \cdot 0$ & $5 \cdot 9$ & 94 \\
\hline & 4 & $4 \cdot 2$ & $6 \cdot 3$ & \\
\hline & 5 & 46 & $6 \cdot 2$ & 6 \\
\hline & 6 & $3 \cdot I$ & $6 \cdot 6$ & IC \\
\hline & 7 & $I \cdot O$ & $3 \cdot 5$ & \\
\hline & 9 & $2 \cdot 9$ & $6 \cdot 7$ & \\
\hline & Io & $2 \cdot 9$ & 5.0 & \\
\hline & I I & $4^{\circ} \circ$ & $5 \cdot 6$ & \\
\hline & 12 & 47 & $5 \cdot 3$ & \\
\hline & I 3 & $6 \cdot 8$ & $6 \cdot 8$ & \\
\hline & I4 & $2 \cdot 5$ & $4 \cdot 8$ & 72 \\
\hline Fish meals: & $\mathrm{FM}_{3}$ & 3.4 & $3 \cdot 6$ & \\
\hline & 6 & $4 \cdot 2$ & $6 \cdot 6$ & \\
\hline & 7 & $3 \cdot 2$ & $6 \cdot 7$ & $\mathrm{I}$ \\
\hline & I 5 & $4 \cdot 5$ & $6 \cdot 1$ & \\
\hline & 17 & 47 & 49 & \\
\hline & 21 & $5 \cdot 2$ & & \\
\hline
\end{tabular}

Code numbers from Boyne et al. (I96I).

* Values from Boyne et al. (I96r).

The values in Table 3 for available lysine and methionine in samples of cod fillet and anchovy meal include values from Carpenter et al. (1963) and Miller et al. (1965). It will be seen that with Tetrahymena assays and the FDNB method similar values were obtained for available lysine, but there was a tendency for Tetrahymena values to be lower in samples with lower available lysine content. 
Table 4 shows available lysine values obtained in Tetrahymena assays of groundnut, soya-bean and cottonseed meals, together with the corresponding GPV from Duckworth, Woodham \& McDonald (I96I).

Table 3. Available lysine and methionine $(g / 16 g N)$ in cod fillets and anchovy meals

\begin{tabular}{|c|c|c|c|c|c|c|}
\hline \multirow[b]{2}{*}{ Sample } & \multicolumn{3}{|c|}{ Available lysine } & \multicolumn{3}{|c|}{ Available methionine } \\
\hline & Tetrahymena & FDNB* & $\begin{array}{l}\text { Chick } \\
\text { assay* }\end{array}$ & Tetrahymena & $\begin{array}{l}\text { Strep. } \\
\text { zymogenes* }\end{array}$ & $\begin{array}{l}\text { Chick } \\
\text { assay* }\end{array}$ \\
\hline \multicolumn{7}{|l|}{ od fillets: } \\
\hline $\begin{array}{l}\mathrm{C}_{23} \\
\mathrm{C}_{24}\end{array}$ & $\begin{array}{l}8 \cdot 6 \\
0.8\end{array}$ & $\begin{array}{c}8 \cdot 8 \\
9 \cdot 0\end{array}$ & $\begin{array}{l}\text { II } 2 \\
10 \cdot 2\end{array}$ & $\begin{array}{l}3.3 \\
3.2\end{array}$ & $\begin{array}{l}3 \cdot 6 \\
3 \cdot 3\end{array}$ & $\begin{array}{l}3 \cdot 6 \\
3 \cdot 2\end{array}$ \\
\hline $\mathrm{C} 26$ & 8.0 & $8 \cdot 2$ & G. I & 3.4 & $2 \cdot 9$ & 2.9 \\
\hline $\mathrm{C}_{29}$ & $8 \cdot \mathrm{I}$ & $7 \cdot 0$ & $9 \cdot I$ & $2 \cdot 9$ & 3.5 & $3 \cdot 6$ \\
\hline $\mathrm{C}_{25}$ & $4 \cdot 2$ & 4.7 & 0.2 & $x \cdot 2$ & $1 \cdot 3$ & 0.4 \\
\hline $\mathrm{C}_{35}$ & $6-7$ & $5 \cdot 9$ & $5 \cdot 8$ & 3.2 & $2 \cdot 0$ & $2: 2$ \\
\hline$X+36$ & $7 \cdot \mathrm{I}$ & $8.7 \dagger$ & $9 \cdot 7 \dagger$ & $2 \cdot I$ & 一 & - \\
\hline $\mathrm{X}_{137}$ & $5 \cdot 8$ & $7.25 \dagger$ & $7 \cdot 3 \dagger^{\dagger}$ & $2 \cdot 7$ & - & - \\
\hline \multicolumn{7}{|l|}{ Anchovy $m$} \\
\hline $\mathrm{X}$ IIgB & $4 \cdot 6$ & $6.85 \dagger$ & $8 \cdot 5 \dagger$ & $2 \cdot 0$ & $\ldots$ & - \\
\hline $\mathrm{XI20B}$ & $2 \cdot I$ & $3.9 \dagger$ & $4 \cdot 3 \dagger$ & 0.7 & - & - \\
\hline
\end{tabular}

Code numbers $\mathrm{C}_{23}-\mathrm{C}_{35}$ from Miller et al. (1965).

Code numbers X $\mathrm{X}_{19} \mathrm{~B}-\mathrm{X}_{13} 7$ from Carpenter et al. (1963).

* Unless otherwise indicated, values from Miller et al. (I965).

$\dagger$ From Carpenter et al. (1963).

Table 4. Available lysine $(\mathrm{g} / \mathrm{I} 6 \mathrm{~g} \mathrm{~N})$ in groundnut meals, soya-bean meals and cottonseed meals

Available lysine

Sample (Tetrahymena) GPv* Total lysinet

Groundnut meals:

$\begin{array}{rlll}\text { GN }_{3} & 3 \cdot 8 & 47 & 3 \cdot 53-4 \cdot 35 \\ 5 & 3 \cdot 3 & 50 & \\ 7 & 2 \cdot 8 & 56 & \\ 8 & 3 \cdot 5 & 42 & \\ 12 & 3 \cdot 2 & 64 & \end{array}$

Soya-bean meals:

$\begin{array}{rrr}\text { SB I } & 5 \cdot 8 & 93 \\ 2 & 5 \cdot 4 & 71 \\ 3 & 5 \cdot 4 & 59 \\ 7 & 5 \cdot 0 & 87 \\ 18 & 6 \cdot 0 & 77 \\ 21 & 5 \cdot 8 & 60\end{array}$

Cottonseed meals:

$\begin{array}{rlll}\text { CM 6 } & 3 \cdot 6 & 64 & 4 \cdot 2-4 \cdot 65 \\ 19 & 2 \cdot 0 & 65 & \\ 52 & 1 \cdot 4 & 27 & \\ 56 & 2 \cdot 0 & 56 \\ 59 & 1 \cdot 1 & 38\end{array}$

Code numbers from Duckworth et al. (196r).

* Values from Duckworth et al. (1961).

$\dagger$ Values frorn Hopper (1958). 
Statistical examination of the values in Tables 2 and 3 revealed various correlations and regressions between Tetrahymena available lysine values $(X)$ and the chemically determined (FDNB) available lysine values $(Y)$. For meat meals $Y=0.37 X+2 \cdot 77$ $(r=0.56, P<0.1)$, for whale meat meals $Y=0.40 X+4.19(r=0.59, P<0.05)$ and for fish meals and the cod fillet samples $Y=0.60 X+3.12(r=0.80, P<0.001)$. Combining the values for meat meals and whale meat meals gave the equation $Y=0.63 X+2.73(r=0.63, P<0.01)$.

Comparison of Tetrahymena available lysine values $(X)$ and gross protein values $(Y)$ in Tables 2 and 4 gives for meat meals $Y=9.4 X+43.0(r=0.59, P<0.05)$ and for soya-bean, groundnut and cottonseed meals $Y=7 \cdot 4 X+32 \cdot 1 \quad(r=0.70$, $P<$ o.0r). The correlation for whale meat meals between Tetrahymena available lysine and GPV just failed to reach the $10 \%$ significance level $(r=0.47)$. If the values for meat meals and whale meat meals are combined the equation is $Y=8 \cdot 7 X+5 \mathrm{I} \cdot 6$ $(r=0.59, P<0.01)$.

Table 5. Tetrahymena assays of available lysine and methionine in a sample of solvent-extracted soya-bean meal, before and after various heat treatments

$\begin{array}{ccc} & \begin{array}{c}\text { Available } \\ \text { lysine } \\ (\mathrm{g} 6 \mathrm{~g} \mathrm{~N})\end{array} & \begin{array}{c}\text { Available } \\ \text { methionine } \\ \text { Treatment }\end{array} \\ & \mathrm{g} / \mathrm{1} 6 \mathrm{~g} \mathrm{~N})\end{array}$

Air-dried at room temperature

Autoclaved $\mathrm{I} \frac{\mathrm{T}}{2} \mathrm{~h}$ at $\mathrm{I} 2 \mathrm{I}^{\circ}$

Autoclaved $2 \frac{1}{2} \mathrm{~h}$ at $12 \mathrm{I}^{\circ}$

Toasted in large-scale plant (exposed to

heat $\frac{3}{4}-\mathrm{I}$ h, final temperature

$95-100^{\circ}$ )

$4 \cdot 1$

$4 \cdot 4 \quad I \cdot 8$

$2 \cdot 7 \quad 2 \cdot 0$

$4 \cdot 2 \quad 1 \cdot 6$

Table 6. Tetrahymena assays of available lysine, methionine, arginine and histidine in soya-bean at various stages of processing

\begin{tabular}{lcccc}
\multicolumn{1}{c}{ Sample } & \multicolumn{3}{c}{ Available amino acid $(\mathrm{g} / \mathrm{I} 6 \mathrm{~g} \mathrm{~N})$} \\
Unextracted soya-bean flakes* & Lysine & Methionine & Arginine & Histidine \\
Hexane-extracted meal, untoasted & $5 \cdot 4$ & $\mathrm{I} \cdot 3$ & $7 \cdot 8$ & $\mathrm{I} \cdot 6$ \\
Hexane-extracted meal, toasted & $4 \cdot 5$ & $\mathrm{I} \cdot 4$ & $6 \cdot \mathrm{r}$ & $\mathrm{I} \cdot 8$ \\
& $5 \cdot 0$ & $\mathrm{I} \cdot 3$ & $7 \cdot 5$ & $\mathrm{I} \cdot 6$
\end{tabular}

* Whole beans rolled into flakes.

Table 5 shows the application of Tetrahymena assays to the evaluation of soya-bean meal subjected to various heat treatments. This aspect was thought to be of particular interest, in view of the known susceptibility of lysine to inactivation or destruction by heat (Liener, 1958) and the possibility of heat damage during the processing of oilseeds. The results show a reduction in available lysine caused by heating in the laboratory under severe conditions $\left(2 \frac{1}{2} h\right.$ at $\left.12 \mathrm{r}^{\circ}\right)$ and, in contrast, the lack of damage after a modern commercial desolventizing-toasting process, in which final temperatures

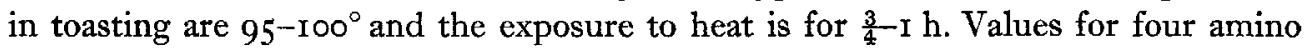
acids in unextracted soya-bean flakes and hexane-extracted meal are shown in Table 6. The differences in lysine content between samples at the three stages of treatment were not statistically significant at the $5 \%$ level. 
Table 7 gives available lysine and methionine values for two 'classical' protein sources, egg and casein, and also illustrates further the scope of Tetrahymena assays by their use for measurement of available amino acids in cereals. The values for total amino acid content are derived from Hopper (1958), with the exception of that for milo, which is from Combs \& Nicholson (1962).

Table 7. Available lysine and methionine $(g / 16 g N)$ in various protein sources

\begin{tabular}{|c|c|c|c|c|}
\hline Source & $\begin{array}{c}\text { Available } \\
\text { lysine } \\
\text { (Tetrahymena) }\end{array}$ & $\begin{array}{c}\text { Total } \\
\text { lysine* }\end{array}$ & $\begin{array}{c}\text { Available } \\
\text { methionine } \\
\text { (Tetrahymena) }\end{array}$ & $\begin{array}{l}\text { Total } \\
\text { methionine* }\end{array}$ \\
\hline Egg & $4.9(1)$ & $7 \cdot 0-7 \cdot 24$ & $3.5(1)$ & $3 \cdot 85-4 \cdot 0$ \\
\hline Casein & $8 \cdot 7(\mathrm{I})$ & $7 \cdot 5-9 \cdot 76$ & $3.9(\mathrm{I})$ & $3.12-350$ \\
\hline Oats & $3.6(\mathrm{I})$ & 3.9 & $\mathrm{I} \cdot 2(\mathrm{I})$ & I. 5 \\
\hline Milo & $I \cdot 0-2 \cdot 5(4)$ & 3 아 & $0.8-I \cdot 0(4)$ & $=\cdot 6+$ \\
\hline Wheat & $I \cdot 0-I \cdot 6(4)$ & $2.7-3.06$ & $I \cdot O-I \cdot 3(5)$ & $0.68-2.5$ \\
\hline Barley & $I \cdot 2-2 \cdot 0(8)$ & $3 \cdot 2-3 \cdot 5$ & $0.5-1 \cdot 7(8)$ & $I \cdot 2-I \cdot 4$ \\
\hline Maize & $I \cdot 3-3 \cdot 0(6)$ & $2 \cdot 3-4 \cdot 5$ & $0.8-1 \cdot 7(6)$ & $0.94-3 . I$ \\
\hline
\end{tabular}

Figures in parentheses are the number of samples assayed.

* Hopper ( $195^{8}$ ), with the exception of the figures for milo.

+ Combs \& Nicholson (1962).

\section{DISCUSSION}

\section{Animal protein sources}

A biological measurement of available lysine, obtained with higher animals, would be the best criterion against which to judge the Tetrahymena available lysine values. However, although chick assay values for lysine and methionine have been published for the samples in Table 3 (Carpenter et al. 1963; Miller et al. 1965), the only values available for the large number of samples in Tables 2 and 4 were FDNB lysine values and GPV.

The values for FDNB-reactive lysine might be supposed to represent the maximum available lysine, as being a determination of the lysine not rendered unavailable by binding of the $\epsilon$-amino group. Any other factor lowering the availability of amino acids, for example the overall digestibility of the protein, could be expected to influence the microbiological assays and give rise to a lower available lysine value than that given by the FDNB procedure.

When the results from Tetrahymena assays of meat meals, whale meals and fish meals in Table 2 are considered, the Tetrahymena values are in general lower than those estimated by the FDNB method. This discrepancy is not apparent for the cod samples of high available lysine content (8-9 g/ $16 \mathrm{~g} \mathrm{~N}$ ) recorded in Table 3 , although a similar tendency for lower Tetrahymena values appears with the samples of cod and anchovy meal of lower FDNB-reactive lysine content. Thus factors other than binding of the $\epsilon$-amino group do appear to have influenced the Tetrahymena assays.

The statistical analyses reflect the situation discussed above, a much better correlation $(r=0.86, P<0.01)$ being found between Tetrahymena available lysine values and FDNB-reactive lysine values for the meals in Table 3, which include mainly samples of higher $(>6 \mathrm{~g} / \mathrm{I} 6 \mathrm{~g} \mathrm{~N})$ available lysine content, than for the meat meals and 
whale meat meals in Table $2(r=0.63 ; P<0.01)$, which include many samples of lower $(<6 \mathrm{~g} / \mathrm{1} 6 \mathrm{~g} \mathrm{~N})$ available lysine content.

The results for cod samples 25 in Table 3 are particularly interesting: with the chick assay Miller et al. (1965) obtained an available lysine value of $0.2 \%$. This result was obviously influenced by factors other than binding of lysine and Miller $e t$ al. (1965) suggested that the low value might be attributable in part to a considerable decrease in protein digestibility. The chick assay for available methionine also gave a very low value, whereas the two different microbiological assays, using the protozoan Tetrahymena and the bacterium Streptococcus zymogenes, gave similar values, considerably higher than those in the chick assays. Such discrepancies between chick and microbiological assays point to the danger of assuming that the available lysine or methionine is a fixed quantity for one protein under all conditions. Investigation of chick assays might show the influence of particle size of the meal under test, as has been recorded for Strep. zymogenes microbiological assays (Ford, 1964).

The GPvs quoted in Table 2 provide the only biological measure of protein quality for comparison with the Tetrahymena available lysine values on these particular samples. The GPV probably reflects, in many instances, the available lysine in the protein concentrate, since the cereal-based basal diet is deficient in lysine. However, there is no direct experimental evidence that lysine is always limiting in the complete test diet, although this supposition could of course be tested by addition of lysine to the complete diet. The correlation between Tetrahymena available lysine values and GPV for meat meals and whale meat meals was similar to that between available lysine values determined by Tetrahymena assays and by the FDNB method. This would be expected from comparison with the data of Boyne et al. (1961), who showed a close correlation between FDNB-reactive lysine and GPV for these samples.

\section{Vegetable protein sources}

The overall correlation between Tetrahymena available lysine figures and GPV $(r=0 \cdot 70)$ for the oilseed meals in Table 4 provides circumstantial evidence of the validity of the Tetrahymena figures, although for any one type of meal this correlation is not apparent. For groundnut meals, the failure to show correlation between the two sets of values may be due to the relatively small range in GPV of the samples examined (42-64) compared with the standard error of \pm 6 for a GPV determination (Boyne et al. 1961).

The available lysine figures obtained in Tetrahymena assays of the groundnut and soya-bean meals in Table 4 are fairly close to the total lysine figures quoted by Hopper (1958). The data suggest that conditions encountered during commercial processing of these oilseeds are not severe enough to induce lysine-carbohydrate binding reactions, a conclusion supported by the values for available lysine in commercially processed soya-bean meals in Tables 5 and 6.

In considering the cottonseed meals in Table 4 the observations of Baliga \& Lyman (x957) on the gossypol-lysine binding reaction are particularly relevant. These authors showed that the lysine in a commercial cottonseed meal was only $54.9 \%$ available for 
rat growth and the bound gossypol was $1 \cdot 32 \%$ of the meal. Reduction of the bound gossypol to $0.49 \%$ increased lysine availability to $70.4 \%$, and in another sample with $0.37 \%$ bound gossypol the availability of lysine was $87.5 \%$. In comparison, the bound gossypol contents of the cottonseed meals in Table 4 ranged from 0.74 to $0.95 \%$, calculated as the difference between total and free gossypol as reported by Boyne et al. (I96r). Thus the low ( $\mathrm{g} / \mathrm{x} 6 \mathrm{~g} \mathrm{~N}$ or less) available lysine values for four of these cottonseed meals can be explained, at least in part, as due to gossypol-lysine reaction.

The values for available lysine and methionine in cereals (Table 7 ) varied considerably between samples of the same type of material. Whether these values reflect difference only in availability, or in total lysine or methionine content is impossible to say on the present evidence. It is, however, interesting to note that Gupta, Dakroury, Harper \& Elvehjem (1958), in experiments using rats, found that the lysine in a sample of maize was only $58 \%$ available and that the lysine in wheat flour was $79 \%$ available. Judgement of the significance of the Tetrahymena values must obviously await further detailed investigation using higher animals. If confirmed for higher animals, the existence of such variations in available lysine and methionine content of one type of cereal would be of considerable importance in planning practical diets for farm animals; in such diets some $50 \%$ of the protein may be contributed by cereals.

\section{General considerations}

One of the most useful features of $T$. pyriformis $\mathrm{W}$ as a test organism for measurement of protein quality is its ability to grow on a wide range of protein sources, including animal protein concentrates, oilseed meals and cereals. The requirement of the organism for lysine makes it a particularly useful analytical tool, and its other essential amino acid requirements suggest the use of Tetrahymena for assay of available isoleucine, leucine, phenylalanine, threonine, tryptophan and valine in addition to the four amino acids dealt with in this paper. In contrast with the Strep. zymogenes assay of available methionine (Ford, 1962, 1964; Waterworth, 1964), assays using Tetrahymena do not require partial predigestion of the sample with proteolytic enzyme, and offer the convenience of estimating the two nutritionally important amino acids, lysine and methionine, with the same organism. Table 3 shows that Tetrahymena assays give values for available methionine similar to those obtained by Miller et al. (1965) using Strep. zymogenes. Comparative tests with the two organisms on a wider range of samples are reported by Boyne, Price, Rosen \& Stott ( 1967 ). Values in the latter report showed Tetrahymena and Strep. zymogenes assays to give similar results for available methionine in whale meat meals, but Tetrahymena assays tended to give higher available methionine figures than Strep. zymogenes assays for the meat meals examined.

No attempt has been made, in the experiments reported here, to estimate the total content, available plus unavailable, of lysine, methionine, arginine or histidine in the samples studied. As will be seen from the range of total lysine and methionine contents quoted in the literature, particularly for methionine in maize and wheat (Table 7), it is impossible to judge the percentage availability of the essential amino acids without 
further measurements on the samples studied. However, values for availability would seem to be of restricted interest; the available amino acid content appears to be the most useful information for use in planning diets for both farm animals and man.

The authors thank Dr G. D. Rosen, Field Investigations and Nutrition Services Ltd., 3 Io Regent Street, London, W I, for his helpful advice and comments on this work. We also thank Dr K. J. Carpenter and his colleagues at the School of Agriculture, University of Cambridge, for the cod fillet and anchovy meal samples, and for providing information concerning those samples before publication.

\section{REFERENCES}

Baliga, B. P. \& Lyman, C. M. (1957). F. Am. Oil Chem. Soc. 34, 21.

Boyne, A. W., Carpenter, K. J. \& Woodham, A. A. (1961). F. Sci. Fd Agric. 12, 832.

Boyne, A. W., Price, S. A., Rosen, G. D. \& Stott, J. A. (1967). Br. F. Nutr. 21. (In the Press.)

Carpenter, K. J. (1960). Biochem. Э. 77, 604.

Carpenter, K. J., Ellinger, G. M., Munro, M. I. \& Rolfe, E. J. (1957). Br. F. Nutr. II, 162.

Carpenter, K. J. March, B. E., Milner, C. K. \& Campbell, R. C. (1963). Br. F. Nutr. 17, $3 \circ 9$.

Combs, G. F. \& Nicholson, J. L. (1962). Feedstuffs 34, no. 43, p. 18.

Duckworth, J., Woodham, A. A. \& McDonald, I. (196I). F. Sci. Fd Agric. 12, 407.

Ford, J. E. (1962). Br. F. Nutr. 16, 409.

Ford, J. E. (1964). Br. F. Nutr. 18, 449 .

Gupta, J. D., Dakroury, A. M., Harper, A. E. \& Elvehjem, C. A. (1958). F. Nutr. 64, 259.

Heiman, V., Carver, J. S. \& Cook, J. W. (1939). Poult. Sci. 18, 464.

Hopper, T. H. (1958). In Processed Plant Protein Foodstuffs, p. 877. [A. M. Altschul, editor.] New York: Academic Press Inc.

Kidder, G. W. \& Dewey, V. C. (I95I). In Biochemistry and Physiology of Protozoa. Vol. I, p. 323. [A. Lwoff, editor.] New York: Academic Press Inc.

Liener, I. E. (1958). In Processed Plant Protein Foodstuffs, p. 79. [A. M. Altschul, editor.] New York: Academic Press Inc.

Miller, E. L., Carpenter, K. J. \& Milner, C. K. (1965). Br. F. Nutr. 19, 547.

Rosen, G. D. \& Fernell, W. R. (1956). Br. F. Nutr. 10, 156.

Stott, J. A., Smith, H. \& Rosen, G. D. (1963). Br. F. Nutr. 17, 227.

Teunisson, D. J. (I96r). Analyt. Biochem. 2, 405.

Waterworth, D. G. (1964). Br. \%. Nutr. 18, 503. 